\title{
Bioavailability of the Sodium Pertechnetate and Morphometry of Organs Isolated from Rats: Study of Possible Pharmacokinetic Interactions of a Ginkgo Biloba Extract
}

Silvana Ramos Farias Moreno ${ }^{1,2^{*}}$, Jorge José Carvalho ${ }^{3}$, Ana Lúcia Nascimento ${ }^{3}$, Mário Pereira $^{3}$, Emely Kazan Rocha ${ }^{4}$, Gláucio Diré ${ }^{2}$, Adriano Arnobio ${ }^{1}$, Luiz Querino de Araújo Caldas $^{1}$ and Mario Bernardo-Filho ${ }^{2}$

${ }^{1}$ Programa de Pós-Graduação em Ciências Médicas; Universidade Federal Fluminense; Rua Marquês de Paraná, 403; Anexo; 24030-210; Niterói - Rio de Janeiro - Brasil. ${ }^{2}$ Departamento de Biofísica e Biometria; ${ }^{3}$ Departamento de Histologia e Embriologia; ${ }^{4}$ Departamento de Biologia Celular e Genética; Instituto de Biologia Roberto de Alcântara Gomes; Universidade do Estado do Rio de Janeiro; Av. 28 de Setembro, 87; 20551-130; srfmoreno@hotmail.com; Rio de Janeiro - RJ - Brasil

\begin{abstract}
Many compounds affect the bioavailability of radiobiocomplexes as radiopharmaceuticals. Ginkgo Biloba extract (EGb) has several effects. The influence of an EGb on the bioavailability of the radiobiocomplex sodium pertechnetate $\left(\mathrm{Na}^{99 m} \mathrm{TcO}_{4}\right)$ and on the morphometry of the organs was evaluated. Rats were treated with EGb and $\mathrm{Na}^{99 m} \mathrm{TcO}_{4}$ was injected. The animals were sacrificed; the radioactivity in the organs was counted. The results showed that EGb altered the $\mathrm{Na}^{99 m} \mathrm{TcO}_{4}$ bioavailability in the kidneys, liver and duodenum. Morphometric analysis of the organs showed significant alterations $(P<0.05)$, probably caused by metabolites generated by EGb and capable of altering the bioavailability of the $\mathrm{Na}^{99 m} \mathrm{TcO}_{4}$.
\end{abstract}

Key words: Ginkgo biloba extract, bioavailability, radiobiocomplex, sodium pertechnetate, morphometry

\section{INTRODUCTION}

Radiobiocomplexes,

known radiopharmaceuticals, are radioactive tracers employed in nuclear medicine for diagnostic and/or treatment of diseases or to study the (i) blood flow; (ii) morphology of organs; (iii) bioavailability and metabolism of drugs (Chandra, 1998, Braga et al., 2000, Gomes et al., 2002). Radiobiocomplexes may be labeled with technetium-99m (Tc-99m), as sodium pertechenetate $\left({ }^{99 \mathrm{~m}} \mathrm{TcO}^{-} \mathrm{Na}\right)$, and used as imaging agents (Hladik III et al., 1987).

The bioavailability of radiobiocomplexes can be recognizably altered by diseases and a wide variety of conditions, such as radiation therapy, drug therapy (medicinal plant or synthetic drugs) and several invasive medical procedures (Diré et al., 2003, Early and Sodee, 1996; Lima et al., 2002; Mattos et al., 2001; Oliveira et al., 2002; Sampsom, 1996, Hladik III et al., 1987). The altered biological behavior caused by diseases

${ }^{*}$ Author for correspondence 
helps the physician to make a diagnosis (Early and Sodee, 1996; Hladik III et al., 1987).

Ginkgo Biloba extract (EGb) is a medicinal plant which comes from the leaves of the ginkgo tree, one of the oldest living plant species (Jacobs and Browner, 2000). This extract has several effects, including: [1] increases the blood flow, [2] acts as platelet activating factor antagonism and [3] prevents the membrane against the damage caused by free radicals (Diamond et al, 2000; Galluzzi et al, 2000; Jacobs and Browner, 2000; Moreno et al, 2001; Pietta, 1999; Yucheng et al, 1996).

Since the study of drug interactions with radiopharmaceuticals is highly relevant and desirable, the purpose of this work was to study the influence of a Ginkgo biloba extract on the bioavailability of the radiobiocomplex sodium pertechnetate and on the morphometry of some organs isolated from the Wistar rats treated with EGb.

\section{MATERIAL AND METHODS}

A solution containing $24 \%$ of a commercial Ginkgo biloba extract (China Jiangsu Medicines and Health Products Lot GB 001128, w/w) was prepared in $0.9 \% \mathrm{NaCl}$. From this solution (crude extract), saline dilutions containing 40 and 400 $\mathrm{mg} / \mathrm{mL}$ of the commercial extract were prepared. These preparations were administrated to female Wistar rats $(\mathrm{n}=5)$ during 6 days (intragastric via). The control group received a solution of $0.9 \%$ NaCl. Tc-99m, as ${ }^{99 \mathrm{~m}} \mathrm{TcO}_{4}^{-} \mathrm{Na}, \quad(0.3 \mathrm{~mL}, 7.4$ $\mathrm{MBq}$ ), recently milked from a Molibdenium99/Technetium-99m generator (Instituto de Pesquisas Energéticas e Nucleares, Comissão Nacional de Energia Nuclear, São Paulo, Brazil), was injected by ocular plexus and the animals were sacrificed after 10 minutes. The organs were isolated (brain, liver, duodenum, heart, kidney, spleen, stomach, pancreas, lung, ovary, blood, bone, muscle and thyroid) and counted in a well counter (Automatic Gamma Counter Packard, USA). The percentages of radioactivity per gram of each organ (\% ATI/g) were calculated. A statistical analysis of the results (ANOVA test, with Dunnet test, $\mathrm{p}<0.05$ ) was performed.

Histological preparations were performed with some organs of interest (liver, kidney and duodenum) from the animals that received EGb $(400 \mathrm{mg} / \mathrm{mL})$ by an intragastric route. The pieces of the organs isolated from the rats (treated and control) were fixed in $2.5 \%$ glutaraldehyde (Riedel-de-Haen) in $0.1 \mathrm{M}$ cacodylate buffer (pH 7.2). The fixative was added with $0.25 \%$ tannic acid (Merck). The postfixation was in $1 \%$ osmium tethroxide (Sigma) $\left(\mathrm{OsO}_{4}\right), \quad 0.8 \%$ potassium ferricyanide and $5 \mathrm{mM}$ calcium chloride $\left(\mathrm{CaCl}_{2}\right)$ in $0.1 \mathrm{M}$ cacodylate buffer. The tissues were dehydrated in acetone and embedded in Epon (Embed-812). Thin sections $(2 \mu \mathrm{m})$ were stained with toluidine blue (Vetec, Brazil) and observed under light microscopy (Olympus BH2-RFCA).

Images of these tissues (glomerulus, hepatocitus and duodenum) were recorded on a computer employing the Nero Pro plus Image Program. The Morphometry Analysis with Mann Whitney test $(\mathrm{P}<0.05)$ was performed. Perimeter and frequency (number of cells/area) were the parameters considered to compare the glomerulus, hepatocytes and duodenum cells obtained from control animals and treated during 6 days with Ginkgo biloba extract $(400 \mathrm{mg} / \mathrm{ml})$.

\section{RESULTS AND DISCUSSION}

Herbs and drugs usually interact in two general ways: pharmacokinetically and pharmacodynamically. Pharmacokinetic interactions (bioavailability) result in alterations in absorption, distribution, metabolism, or elimination of an agent, quantitatively increasing or decreasing the amount that becomes effective in the body (Rotblat et al, 2002).

The effect of the Ginkgo biloba crude extract on the bioavailability of the ${ }^{99 \mathrm{~m}} \mathrm{TcO}_{4}^{-} \mathrm{Na}(\% \mathrm{ATI} / \mathrm{g})$ in the female Wistar rats which had (40 and 400 $\mathrm{mg} / \mathrm{mL}$ ) or had not (control group) received the extract are presented in Table 1. The EGb altered (not significant, $\mathrm{n}=5, \mathrm{p}>0.05$ ) the uptake of the ${ }^{99 \mathrm{~m}} \mathrm{TcO}^{-} \mathrm{Na}$ in the kidneys and liver. A significant $(\mathrm{n}=5, \mathrm{p}<0.05)$ decrease in the uptake of this radiobiocomplex in the duodenum from $1.01 \pm$ 0.37 to $0.55 \pm 0.09$ after the treatment with EGb (40 $\mathrm{mg} / \mathrm{mL}$ ) and from $1.01 \pm 0.37$ to $0.51 \pm 0.36$ after the treatment with EGb $(400 \mathrm{mg} / \mathrm{mL})$ was observed (Table 1).

Morphometric alterations in the kidney and liver due to treatment (in vivo) were observed (Figs. 1 and 2) and were considered significant $(\mathrm{p}<0.05)$. The perimeter $(\mu \mathrm{m})$ of the glomerulus from kidney was significantly $(\mathrm{P}<0.05)$ increased when compared with the control (Fig. 1). 
Table 1 - Effect of a Ginkgo biloba crude extract (40 and 400mg/mL) on bioavailability of Tc-99m: \%ATI/gram of tissue.

\begin{tabular}{l|c|c|c}
\hline Organs & Control & EGb 40 $\mathbf{~ g} / \mathbf{m l}$ & EGb 400 $\mathbf{~ m g} / \mathbf{m l}$ \\
\hline 1. Brain & $0.04 \pm 0.02$ & $0.04 \pm 0.01$ & $0.06 \pm 0.02$ \\
2. Liver & $0.64 \pm 0.32$ & $0.66 \pm 0.29$ & $0.73 \pm 0.36$ \\
3. Duodenum & $1.01 \pm 0.37$ & $0.55 \pm 0.09 *$ & $0.51 \pm 0.36^{*}$ \\
4.Heart & $0.42 \pm 0.17$ & $0.30 \pm 0.17$ & $0.35 \pm 0.08$ \\
5. Kidney & $0.56 \pm 0.18$ & $1.37 \pm 1.36$ & $0.56 \pm 0.27$ \\
6. Spleen & $0,33 \pm 0.12$ & $0.20 \pm 0.11$ & $0.27 \pm 0.07$ \\
7. Lung & $0.61 \pm 0.35$ & $3.22 \pm 0.45$ & $0.55 \pm 0.19$ \\
8. Stomach & $5.55 \pm 3.30$ & $3.71 \pm 1.97$ & $3.38 \pm 1.01$ \\
9.Pancreas & $0.21 \pm 0.15$ & $0.22 \pm 0.24$ & $0.09 \pm 0.04$ \\
10. Blood & $3.43 \pm 1.50$ & $2.34 \pm 0.85$ & $3.34 \pm 0.54$ \\
11.Bony & $0,28 \pm 0.14$ & $0.34 \pm 0.16$ & $0.21 \pm 0.03$ \\
12. Muscle & $0.12 \pm 0.07$ & $0.12 \pm 0.12$ & $0.09 \pm 0.05$ \\
13. Tiroid & $2.72 \pm 1.18$ & $1.62 \pm 0.68$ & $1.10 \pm 1.14$ \\
14. Ovary & $0.24 \pm 0.14$ & $0.15 \pm 0.08$ & $0.24 \pm 0.02$ \\
\hline
\end{tabular}

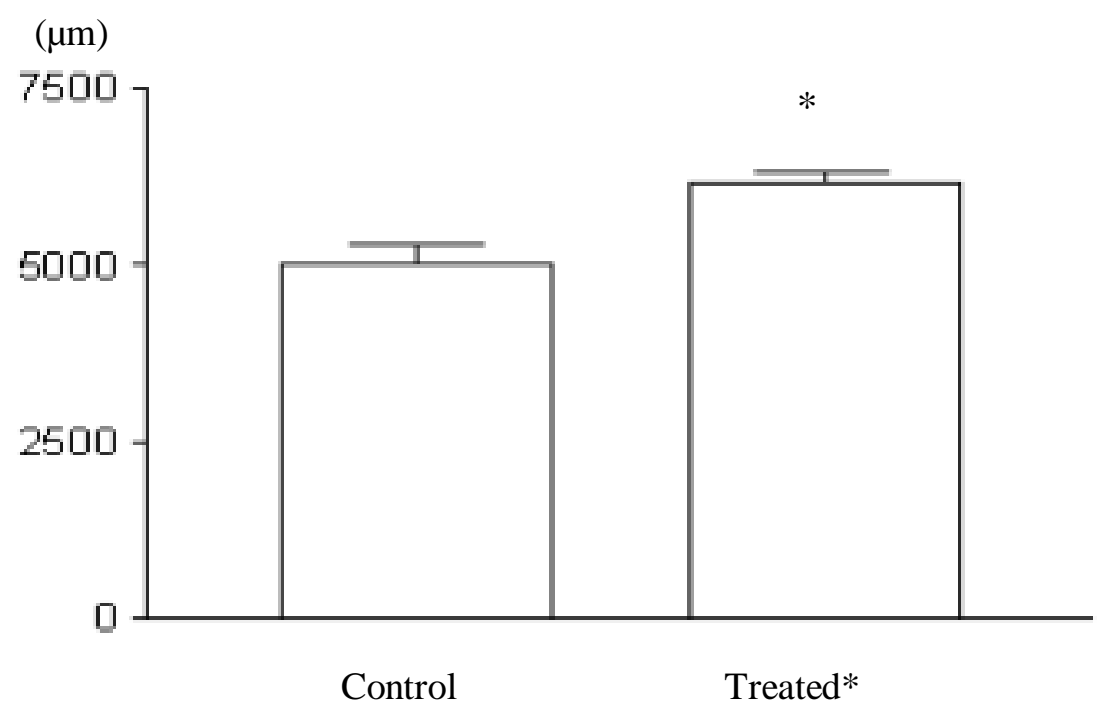

Figure 1 - Morphometric analysis of glomerulus from animals that received EGb $(400 \mathrm{mg} / \mathrm{ml})$ and controls animals 


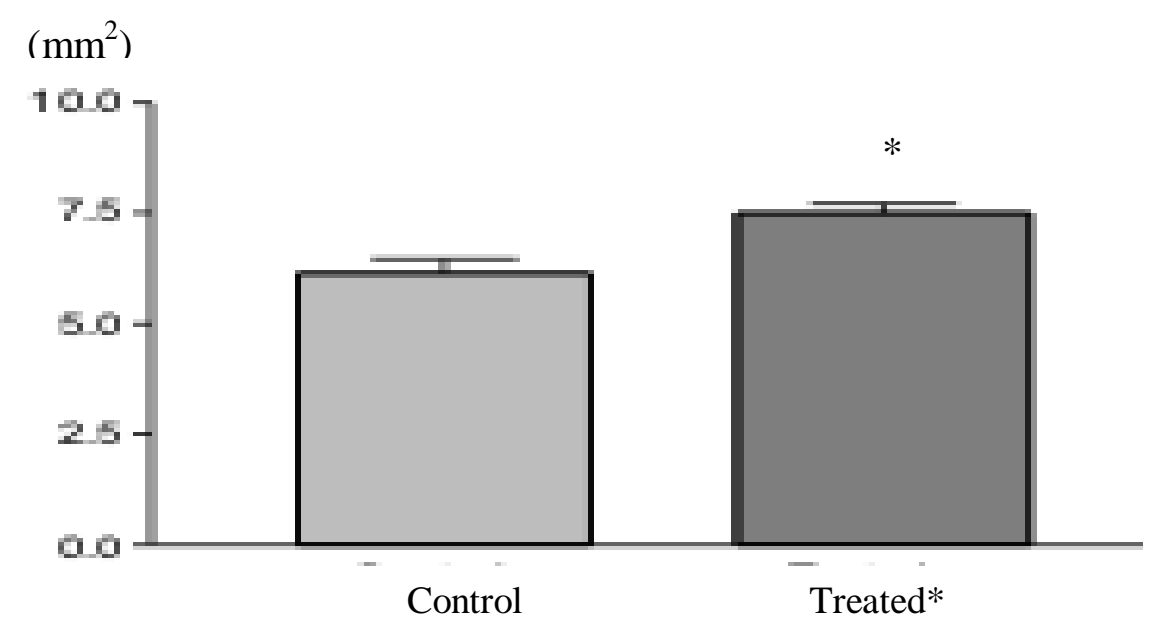

Figure 2 - Morphometric analysis of Hepathocitus number/area from animals that received $\mathrm{EGb}(400 \mathrm{mg} / \mathrm{ml})$ and control animals.

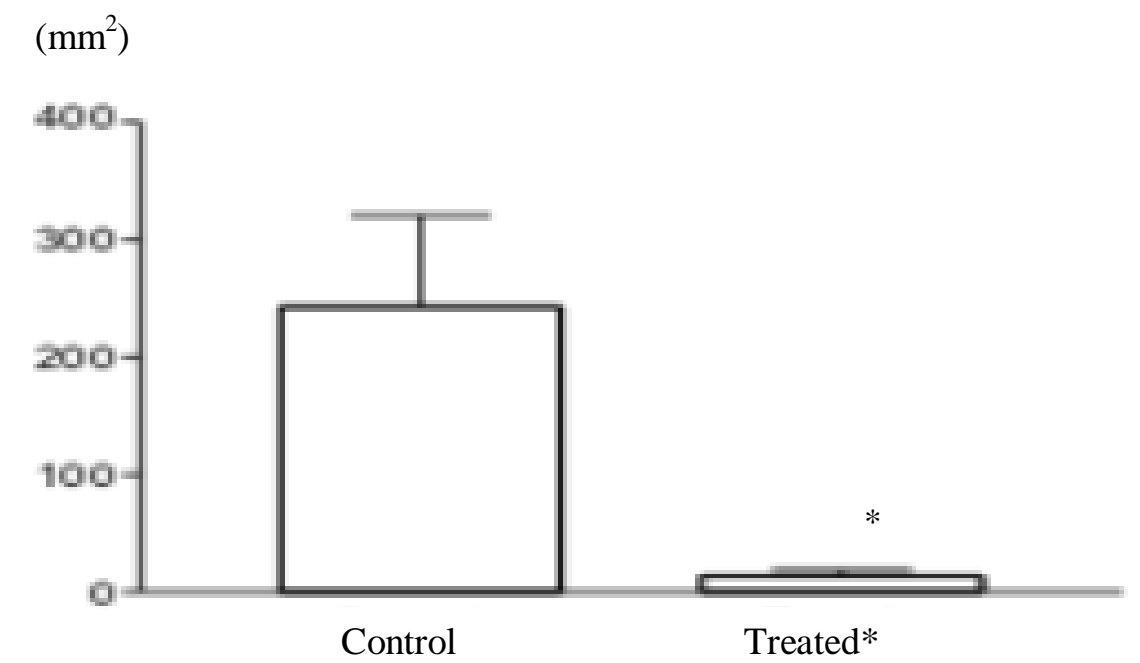

Figure 3 - Morphometric analysis of caliciform cells from animals that received EGb (400 $\mathrm{mg} / \mathrm{ml}$ ) and control animals

The results of the morphometric analysis employing the frequency of cells per area of liver (Fig. 2) have revealed a significant difference $(\mathrm{p}<0.05)$ when compared with the control (no treated animals). The frequency of cells/area of liver in the treated animals was higher than in the control animals. The decrease in the uptake of sodium perthecnetate by the duodenum can be justified by the alterations in the caliciform cells, observed by optical microscopy (image not presented), and the morphometry of this organ (Fig. 3).

The analysis of the results indicates that the in vivo treatment with EGb could generate metabolites with action on specific structures leading to alterations in the morphology of organs and in the bioavailability of $\mathrm{Na}^{99 \mathrm{~m}} \mathrm{TcO}_{4}$. The morphometric alterations observed in the glomerulus could suggest that the glomerular filtration rate should be increased. 
Nevertheless, it is not easy to predict the consequences of the increase in the number of hepatocytes per area in the liver and the reduced number of caliciform cells in the duodenum as a consequence of the metabolization of the Ginkgo biloba extract.

In conclusion, the experimental model employed in this study may be a suitable method for evaluating pharmacokinetic interactions with Ginkgo Biloba extract. Moreover, to better understand the mechanism of action of the Ginkgo biloba extract in the uptake of $\mathrm{Na}^{99 \mathrm{~m}} \mathrm{TcO}_{4}$ by organs, experiments with scavengers of reactive oxygen species and chelating agents are now in progress. Electron microscopy studies will also be done to evaluate whether the changes that were found under light microscropy were capable of promoting ultrastructural alterations.

After six days of treatment (intragastric route) with crude EGb (control, 40 and $400 \mathrm{mg} / \mathrm{mL}$ ), female Wistar rats $(\mathrm{n}=5)$ received $0.3 \mathrm{~mL}$ of $\mathrm{Tc}-99 \mathrm{~m}$ (endovenous via). The animals were sacrificed, the organs isolated and \%ATI/gram determined. Blood ( $1 \mathrm{ml}$ was considered to be 1 gram). $* \mathrm{P}<0.05$.

Morphometry analysis with Mann Whitney test (P value $=0.0079 *, \quad \mathrm{P}<0.05)$. Perimeter is the parameter considered for comparison of glomerulus (kidney) obtained from control animals and treated during six days with Ginkgo biloba extract $(400 \mathrm{~g} / \mathrm{ml})$.

Morphometric Analysis with Mann Whitney test $(\mathrm{P}$ value $=0.0159 *, \mathrm{P}<0.05)$. Number cells/area is the parameter considered for comparison of hepatocitus (liver) obtained from animals controls and treated during 6 days with Ginkgo biloba extract $(400 \mathrm{mg} / \mathrm{ml})$.

Morphometric Analysis with Mann Whitney test ( $\mathrm{P}$ value $=\mathrm{P}<0.05$. $* \mathrm{P}=0.0079)$. Number of cells/area is the parameter considered for comparison of caliciform cells (of duodenum) obtained from control animals and treated during six days with Ginkgo biloba extract $(400 \mathrm{mg} / \mathrm{ml})$.

\section{ACKNOWLEDGEMENTS}

This research was supported by the Coordenação de Aperfeiçoamento de Pessoal de Nível Superior (CAPES), Fundação de Amparo a Pesquisa do Estado do Rio de Janeiro (FAPERJ), Conselho Nacional de Desenvolvimento Científico e Tecnológico (CNPq), Universidade Federal
Fluminense (UFF) and Universidade do Estado do Rio de Janeiro (UERJ).

\section{RESUMO}

Substâncias podem interferir na biodisponibilidade de radiobiocomplexos, como os radiofármacos. $\mathrm{O}$ extrato de Ginkgo Biloba (EGb) apresenta efeitos. Avaliou-se a influência de um EGb na biodisponibilidade do pertecnetato de sódio $\left({ }^{99 \mathrm{~m}} \mathrm{TcO}^{-} \mathrm{Na}\right)$ e na morfometria de órgãos de ratos que foram tratados com EGb. ${ }^{99} \mathrm{TcO}^{-} \mathrm{Na}$ foi injetado, os animais sacrificados e a radioatividade nos órgãos contada. Os resultados mostraram que o EGb alterou a biodisponibilidade do ${ }^{99 m} \mathrm{TcO}^{-}{ }_{4} \mathrm{Na}$ em rins, fígado e duodeno e alterações morfométricas significativas $(p<0.05)$ foram encontradas. Sugere-se que o EGb poderia gerar metabólitos capazes de alterar morfometricamente os órgãos citados e alterar a biodisponibilidade do ${ }^{99 \mathrm{~m}} \mathrm{TcO}^{-}{ }_{4} \mathrm{Na}$.

\section{REFERENCES}

Braga, A. C. S.; Oliveira, M. B. N.; Feliciano, G. D.; Reiniger, I. W.; Oliveira, J. F.; Silva, C. R. and Bernardo-Filho, M. (2000), The Effect of Drugs on the Labeling of Blood Elements with Technetium ${ }^{-99 m}$. Curr. Pharm. Design, 6, 1179-1191.

Capriles, P. V. S. Z.; Dias, A. P. M.; Costa, T. E. M. N.; Oliveira, M. B. N.; Faria, M. V. C.; Moura, E. G.; Abreu, B. A. L. and Bernardo-Filho, M. (2002), Effect of eggplant extract on the in vitro labeling of blood elements with technetium ${ }^{-99}$ and on the biodistribution of sodium pertechnetate in rats. Cel. Mol Biol., 48, 771-776.

Chandra, R. (1998), Nuclear Medicine Physics the Basics. $5^{\text {th }}$ edition. New York: Willians and Wilkins.

Diamond, B. J.; Shiflet, S. C.; Fewel, N.; Matheis, R. J; Noskin, O and Richards, J. A. (2000), Ginkgo biloba extract: Mechanisms and clinical indications. Arch. Phys. Med. Rehab., 81, 668-678.

Diré, G. F.; Lima, E.; Gomes, M. L.; Moreno, S.; Faria, M. V. C.; Jales, R. L.; Catanho, M. T. J. A. and Bernardo-Filho, M. (2003), Evaluation of the Biological Effects of a Natural Extract of Chayotte (Sechium edule): A Molecular and Cellular Analysis. Pak. J. Nut., 2, 249-253.

Early, P. J. and Sodee, D. B. (1996), Principles and pratice of nuclear medicine. Toronto : Mosby Year Book. 877 pp. 
Galluzzi, S.; Zanetti, G.; Binetti, G.; Trabucchi, M. and Frisoni, G. B. (2000), Coma in patient with Alzheimer's disease takinglow dose treated Ginkgo biloba. J. Neur. Neurosur. Psych., 68, 679-680.

Gomes, M. L.; Oliveira, M. N. and Bernardo-Filho, M. (2002), Drug interaction with radiopharmaceuticals: effect on the labeling of red blood cells with technetium-99m and on the bioavailability of radiopharmaceuticals. Braz. Arch. Biol. Technol., 45, 143-149.

Hesslewood, S. and Leung, E. (1994), Drug interactions with radiopharmaceuticals. Eur. J. Nucl. Med., 21, 348-356.

Hladik III, W. B; Saha, G. B. and Study, K. T. (1987), Essentials of nuclear medicine science. London : Williams and Wilkins.

Jacobs, B. P. and Browner, W. S. (2000), Ginkgo biloba: a living fossil. Am. J. Med., 108, 341-342.

Lima, E. A C.; Diré, G.; Mattos, D.; Freitas, R. S.; Gomes, M. L.; Oliveira, M. B. N.; Faria, M. V. C.; Jales, R. L. and Bernardo-Filho, M. (2002), Effect of an extract of cauliflower (leaf) on the labeling of blood elements with technetium-99m and on the survival of Escherichia coli AB1157 submitted to the treatment with stannous chloride. Food Chem. Toxicol., 40, 919-923.

Mattos, D. M. M.; Gomes, M. L.; Freitas, R. S.; Moreno, S.; Nascimento, A. L. R.; Carvalho, J. J. and Bernardo-Filho, M. (2001), Vincristine Toxicity: The Effect on the Biodistributium of radiopharmaceutical and in the Optical Microscopy organs isolated from the treated Animals. J. Labeled Cpd. Radiopharm., 44, 477-479.
Moreno, S. R.; Diré, G. F.; Freitas, R.; Mattos, D.; Gomes, M.; Farah, M.; Lima-Filho, G.; Rocha, E. K. and Bernardo-Filho, M. (2001), Effect of Ginkgo biloba on the in vitro labeling of red blood cells and plasma proteins with Technetium ${ }^{-99 m}$. J. Labeled Cpd. Radiopharm., 44, 663-641.

Oliveira, J. F.; Ávila, A. S.; Braga, A. C. S.; Oliveira, M. B. N.; Boasquevisque, R. L.; Jales, R. L. C.; Cardoso, V. N. and Bernardo-Filho, M. (2002), Effect of extract of medicinal plants on the labeling of blood elements with Technetium ${ }^{-99 m}$ and on the morphology of red blood cells: I-a study with Paullinia cupana. Fitoterapia, 73, 305-312.

Oliveira, J. F.; Oliveira, M. B. N.; Ávila, A. S.; Braga, A. C. S.; Catanho, M. T. J. A.; Jales, R. L. C.; Cardoso, V. N. and Bernardo-Filho, M. (2003), Assessment of the effect of Fucus vesiculosus extract on the labeling of blood constituents with technetium$99 \mathrm{~m}$ and the histological modifications on the shape of the red blood cells. Food Chem.Toxicol., 41,15-20.

Pietta, P. G. (1999), Flavonoids as Antioxidants. J. Nat. Prod., 63, 1035-1042.

Rotblat, M. and Ziment, I. (2002), Evidence-based herbal medicine. Philadelphia : Hanley and Belfus, Inc. Medical Publishers.

Sampsom, C. B. (1996), Complications and difficulties in radiolabelling blood cells: a review. Nucl. Med. Comm., 117, 648-658.

Yucheng, N.; Baolu, Z.; Jingwu, H. and Wenjuan, X. (1996), Preventive effect of Ginkgo biloba extract on apoptosis in rats cerebellar neuronal cells induced by hydroxyl radicals. Neurosc. Lett., 214, 115-118.

Received: June 29, 2005;

Revised: July 14, 2005; Accepted: August 01, 2005. 